\title{
Early Childhood Character Education in Japan
}

\author{
Budi Mulyadi* \\ Faculty of Humanities, Diponegoro University
}

\begin{abstract}
Character education has a very important role in shaping the superior character of Japanese society. Compared to Indonesia, Japan has long designed and implemented character education for all levels of education. Since 1970 Japan has begun to develop a character-based curriculum that has begun to be applied at the kindergarten and elementary school level. Japan recognizes the importance of character education starting at the age of children because educating characters in children will be easier to do than educating teenage or adult characters. Implementation of character education in early childhood in Japan prioritizes character education that can bring out superior characters such as courage, independence, discipline, responsibility, cooperation, and socializing. To bring out these characters, the application of early childhood character education in Japan places great importance on moral and personality education. Through moral education and personality, the characters are brave, independent, disciplined, responsible, cooperating, and socializing. Moral and personality education is not taught through special subjects but is applied in everyday life. And this is characteristic of the application of early childhood character education in Japan
\end{abstract}

Keywords: Early Childhood, Japan, Character Education

\section{Introduction}

Japan is one of the countries in the world that is famous for superior in the character of its human resources. Some of the superior characters known to the world that the Japanese have included being hard-working, disciplined, honest, innovative. These superior characters possessed by the Japanese are inseparable from their success in implementing character education starting from the age of the children. Japanese people realize the importance of character education starting from the age of children because educating characters in children will be easier to do than educating the character of adolescents or adults.

Part of Japanese cultural belief towards children is that they are masshiro (pure white).This belief of the masshiro child means that children are believed to be greatly influenced, colored even, by their caretakers' actions and attitudes. It is therefore considered important to foster a child in the right way, nurturing within it a heart full of

\footnotetext{
*Corresponding author: budi.mulyadi09@gmail.com
} 
emotions and closeness to others. There is a Japanese proverb that states that "The soul of a three-year-old until a hundred." (三つ子の魂百まで), giving further support to the idea that in Japanese cultural belief, a child's early childhood [1].

Children are likened to blank paper that has not been filled with anything so that the good character education taught to children will be easily embedded in their minds and imprints into adulthood. Success in building superior character is also influenced by government policies in the field of education. Education in Japan aims to develop personality fully by striving to build healthy people of mind and body, love truth and justice, respect individuals, respect work, and have a deep sense of responsibility and a spirit of independence as the builders of a peaceful country and society [2]. To achieve this goal the Japanese government is very concerned about character education starting early childhood because the successful application of character education in early childhood will be the foundation of expected character formation that is adjusted to the educational goals in Japan in general as described above.

If the Indonesian state plans to implement character education for all levels of education in Indonesia from the level of early childhood education to tertiary education starting in 2010, the country of Japan has long carried out character education programs. It is said that since 1970 Japan has begun to develop a character-based curriculum that began to be instilled in kindergartens and elementary schools. The Japanese think that early education and elementary school children are a golden period to instill character. Besides this, early character education is not only done in formal institutions but character education starts from the family. Families and schools work together to form the character of early childhood so as to produce a superior foundation for human resources. Japan recognizes that if it wants to succeed in development, what must first be built in the character of its human resources. This can be proven by Japan being a developed country in various fields of life even though seen from its natural resource wealth Japan is not as rich as Indonesia. Japan does not produce petroleum, gas, minerals but they succeeded in building their nation to become a superior nation and defeat other nations including the nations of Europe. This is because they have superior human resources and have a strong character as a result of character education that starts from an early age.

In terms of children's character education, Japan has its own uniqueness that will not be found in other countries including Indonesia. Informal institutions such as kindergarten character education in Japan is focused on moral and personality education that is not taught through special subjects but is directly practiced in daily life. Japanese education curriculum does not specialize in moral teaching in a subject. There is no measurement tool to measure students' competence on the matter. Moral education is delivered in the form of a hidden curriculum. Guidance on good social behavior is delivered by the homeroom teacher in the form of discussion or a special direction. Although not used as a special subject, moral education which is part of character education is very prominent. Children in Japan learn ordinances and behave with others, older people, younger, unknown, and other manners. They also learn about rules at school, family, and public places.

Radjasa in his paper explains that in kindergarten in Japan, children are educated to become independent, responsible, sensitive, and caring to the environment, appreciative of others, disciplined, and cooperative. The process is applied through various activities such as sports, arts, and crafts instead of thorough explanation and memorization. Children are trained to perform good activities, and not to be lectured about goodness. Radjasa also explains one of the principles of education at kindergarten in Japan that become one of character education forms is Students must be trained to cooperate. They must understand their own roles and learn to appreciate others' roles. Through playing together, they learn to understand each other, and to apologize to one another when there is a disagreement. Activities like having meals together, playing in nature, performing rhythmic exercise 
indoors, doing sport outdoors, and singing together is included in the daily routine [3].

As for non-formal institutions, the family has an important role in educating the character of children. The general assumption is that the family is the primary moral educator for children. Parents are the children's first moral teacher, the most enduring influencers. Children change teachers every year, but they have one parent throughout their growing period. A child's parent relationship also contains special emotional significance that can cause children to feel loved and valued or otherwise feel unloved and unworthy [4]. Things like this are applied by families in Japan in their children's character education. In Japan, the one who has the most role in character education related to morality and virtuous teachings is a mother. The Japanese education and culture system seems to rely heavily on the role of women in raising, educating, and teaching children outside of school. Because of that in Japan, the "Ryosai Kenbo" policy has adhered to 良妻賢母which means "good wife and wise mother" who establishes the position of women as household affairs managers and nurses of the nation's children. This philosophy has always been the mindset of the Japanese nation and has been the key to education for generations [5].

Many of the uniqueness of the early childhood character education system in Japan is different from the character education system in Indonesia. The purpose of this study is to describe the implementation of early childhood character education models in Japan.

\section{Research Methods}

This research is a literature study. A literature study is used to make an analysis of the problem being studied. Besides that, several books at the same time also constitute secondary data. Here are some steps in the method used.

1. Observation: this method is used to get a picture of the lives of Japanese people and society. The images obtained are the main material/data to be analyzed,

2. Interview: this technique is carried out to get a more detailed picture of the study material. Interviews were conducted with Japanese people, both lecturers, and students, or volunteers from Japan,

3. Classification: after sufficient material is obtained, material classification is carried out both in terms of urgency and in terms of the type of material/data,

4. Analysis: analysis is carried out on the material that has been obtained and reinforced material/information from existing books,

5. Interpretation: this method is used by interpreting to get a proper understanding of the study material, to get the basic ideas of the study material, and an overview of how it actually applies,

6. Synthesis: from the results of the study several aspects that have been studied and studied using deductive logic obtained a synthesis. This synthesis is a conclusion that answers the problem raised,

7. Description: all research material, scientific studies, and application trials, until the final conclusions are described by maintaining the principle of coherence.

\section{Research Methods}

\subsection{Definition of Character Education}

Education is a process to change the identity of a student to be more advanced. According to experts, there are several definitions that explore the definition of education itself. For example, education means maintaining and giving training. In maintaining practice, it is necessary to have teachings, guidance, and leadership regarding morals and intelligence of 
the mind [6]. Education is a process that occurs continuously (eternal) from a higher adjustment for human beings who have developed physically and mentally free and aware of God as manifested in the natural surroundings, intellectual, emotional and humanity of humans [7].

As for the characters in the Indonesian Language Dictionary, characters are interpreted as mental, moral, or moral qualities that distinguish one person from another: character, character. Meanwhile, according to Thomas Lickona, character education is about being a character school where the school is the best place to instill character.

\subsection{Common Characters of the Japanese Nation}

Murni Ramli in her book entitled "Being a Japanese Character and Cultured Person" describes some of the common characters of the Japanese nation that have been known to the world. Here are some of the characters of the Japanese nation explained by Murni Ramli in her book.

\subsubsection{Discipline}

Discipline (Kiritsu $=$ 規律 $)$ or shitsuke ( 躾) is the most prominent character in Japanese society. There are several thoughts that explain the reasons why Japanese people are very strong in terms of discipline. One of them argued that the Japanese discipline was born during the Edo period. There are also those who think Japanese people are born with genetic discipline. However, Murni Ramli explained that the Japanese discipline is not inherently genetic, but was born from the formation and education since childhood, which then gave birth to understanding, awareness, and sensitivity to various problems that arise in the community.

\subsubsection{Appreciate time}

There is no nation in this world that values time more than the Japanese. In Japanese society, the term jikan genshu is well-known which means "tight time". Time is very meaningful for Japanese people. For accuracy and respect for the importance of time can be seen in the scheduling system of public transportation such as trains and buses. The train departs and arrives according to a predetermined time schedule that even reaches seconds. Likewise in any event, such as meetings begin in accordance with a predetermined time schedule. There is no such thing as rubber time in Indonesia.

\subsubsection{Hard-working}

Another character possessed by the Japanese known to the world is hard work. Japanese hard work is often symbolized by the phrase "ganbarimasu" which means I will try hard. This hard-working character is what makes Japan a developed country in various fields of life. Japan's natural resources are not so abundant but thanks to their hard work they can overcome the lack of natural resources with high technology innovation so that with technology, they can rule the world.

\subsubsection{The detail and thorough in working}

Murni Ramli in his book explained that besides being fond of working hard, the Japanese were also very detailed in the decomposition and work so that in Japanese culture the term 
komakai sagyou appeared to have detailed meaning at work. They did not like instant work and really appreciated the process that was orderly and systematic and detailed works. Early Childhood Education in Japan

In general, early childhood education in Japan is divided into two namely:

\subsubsection{Youchien}

In Indonesian youchien can be interpreted as kindergarten. This institution is under the ministry of Japanese Culture in Sports Science and Technology called Monbukagakusho. Kindergarten education in Japan is based on the following three things.

1. Children get as much experience as possible

2. Children learn through play

3. Children develop according to the nature and character of each

The purpose of kindergarten education in Japan is to build children's strength to live and have a strong foundation for living on their next steps in life [8].

\subsection{Houikuen}

Hoikuen in Indonesia can be interpreted as a Daycare Center (TPA). This institution is under the ministry of health, labor, and welfare (Kousei Roudou Shou).

The purposes of TPA in Japan are as follows.

1. The purposes of Early Childhood Education are the same as Kindergarten Objectives which include 5 aspects

a. Physical and mental health

b. Social relations

c. Relationships with the environment and surrounding communities

d. Language skill

e. The ability of artistic and creative expression

2. The purpose as an institution that helps parents take care of children with family, community and the surrounding environment [9].

\subsection{The Implementation of Early Childhood Character Education in Japan}

The implementation of early childhood character education in Japan is held in a moderate manner adjusted to the physical and mental development of children. In the Kindergarten and TPA education system in Japan, children are trained to live brave, independent, disciplined, responsible, work together, and socialize.

To train brave characters, schools do not allow parents to wait for their children at school as is often the case in kindergarten schools in Indonesia where many parents are waiting for their children outside the classroom until school is finished. In Japan, parents do not accompany their children at school even though it is only the first day and the child cries [10]. Kindergarten teachers in Japan will make every effort so that kindergarten children are happy and immediately adapt to the school environment. With the implementation of a system like this, early childhood children in Japan have been trained to become people who dare to enter a new environment, dare to separate temporarily with parents, dare to socialize in a new place. This system is also done so that children are not spoiled and always depend on their parents. To build an independent character, in Japan children aged 3 years and over, begin to get used to removing the entire contents of the bag and putting the equipment in the places provided. For example, a hand towel is hung on the clothesline, a toothbrush and a gargle cup are placed around the sink, a drinking flask is 
placed on a thermos rack, a presence book is taken out of a bag, filled and placed on the teacher's desk, a sweater is removed and hung on a clothes rack and etc. At lunchtime, the children are trained to be independent. They have to eat by themselves and then clean their own dining table. Such activities must all be done alone by kindergarten children in Japan with the aim to practice independence from an early age and to eliminate the nature of relying on teachers. Kindergarten teachers in Japan are not allowed to spoil kindergarten children by helping the above activities.

To practice discipline, kindergarten children in Japan are required to be able to open their own shoes and place them neatly on the shoe rack that has been provided. Children are also taught to store items such as bags, jackets, food containers, umbrellas in the space provided. Children are also taught to dispose of trash in their place. This is also done with the aim of fostering a love of cleanliness in the souls of children. Practicing discipline is also done by teaching ethics in using the toilet such as using enough tissue and water, flushing water after using the toilet, turning off the lights before leaving the toilet, rearranging toilet slippers. From small activities like these kindergarten children in Japan learn the discipline that will be embedded in their souls until adulthood. To build a responsible character, the kindergarten teacher class makes an effort by dividing children into groups of 5-6 people. Each group is given a special responsibility, for example, there is a group that is responsible for maintaining class cleanliness, serving lunch, caring for class pets, and others. That responsibility is rotated every week or every month. Group members are changed regularly. This activity indirectly fosters the nature of responsibility in early childhood in Japan as well as fostering a social like nature. When children are given the responsibility to carry out the task, they will be happy and full of responsibility to carry out the task. They do it happily and don't feel burdened. The activities above also train Japanese children to be able to work together in groups to complete a task given by the teacher.

Kindergarten children in Japan have not been taught how to read, write, and count. At an early age, children are prepared to be brave, disciplined, independent, and responsible individuals. Lessons are given while playing. With such a system, Japanese education is very successful the same as education in other developed countries.

\section{Conclusion}

The implementation of early childhood character education in Japan is carried out with careful planning by the Japanese government so that the model of early childhood character education in Japan can be used as an example by other countries because it is proven that the Japanese character education has succeeded in producing a generation that excels in various fields of life so that Japan can be a developed country on a par with America and European countries. The importance of character education being implemented as early as possible for early childhood has been understood by Japan so that the policy in the application of early childhood character education is carried out as seriously and as fully as possible so that Japan can be said to be a successful country in implementing a character education system that should be emulated by other countries including Indonesia. 


\section{References}

1. Agnar D H, David, The Free Spirit in Japanese Kindergarten, Thesis, Leidbeinandi: Gunnella Porgeirsdóttir (2017)

2. Susilo, Taufik Adi, Spirit Jepang, Yogyakarta: Ae-Ruz Media Grup (2017)

3. Radjasa et al, Developing Character Education Grounded on "Abk" (Attitude Before Knowledge) Model for Kindergarten at Raudlatul Athfal State Islamic University "Sunan Kalijaga" Indonesia, IOSR Journal of Research \& Method in Education (IOSRJRME) (2017)

4. Lickona, Thomas, Pendidian Karakter Panduan Lengkap Mendidik Siswa Menjadi Pintar dan Baik, Bandung: Nusa Media (2014)

5. Mulyadi, Budi, Model Pendidikan Karakter Dalam Masyarakat Jepang. Izumi Journal Vol 3 No 1. pp 69-80. Semarang: Undip (2014)

6. Mustofa, Bisri, Psikologi Pendidikan, Yogyakarta: Parama Ilmu (2015)

7. Listyarti, Retno, Pendidikan Karakter dalam Metode Aktif, inovatif dan Kreatif. Jakarta: Erlangga (2012)

8. Juliandi, Putri, Pendidikan Anak Ala Jepang, Jakarta: Gramedia (2014)

9. Juliandi, Putri, Pendidikan Anak Ala Jepang, Jakarta: Gramedia (2014)

10. Ramli, Murni, Menjadi Orang berkarakter dan Berbudaya Jepang, Yogyakarta: Manggar Media (2018) 